\section{Transplant Age Influences Summer Squash Growth and Yield}

\author{
D.S. NeSmith \\ Griffin, GA 30223-1797 \\ Additional index words. Cucurbita pepo
}

Department of Horticulture, The University of Georgia, Georgia Station,

\begin{abstract}
Greenhouse and field experiments were conducted to determine the influence of transplant age on growth and yield of 'Dixie' and 'Senator' summer squash (Cucurbita реро L.). Dry weight and leaf area measurements indicated that 28- to 35-day-old greenhouse-grown transplants grew more slowly after transplanting than plants that were 10,14 , or 21 days old. Older transplants flowered earlier; however, earlier flowering did not result in higher early yields. Transplants of varying ages did not differ greatly in yield and yield components in the field, although all transplants had higher early yields than the directly seeded controls. Results from these experiments suggest that $\mathbf{2 1}$ days may be a reasonable target age for transplanting summer squash. If transplanting were delayed by adverse planting conditions, 21-day-old transplants would likely have at least a 10-day window of flexibility before yields would be reduced notably by additional aging.
\end{abstract}

Transplants are used extensively in the southeastern United States to establish stands of a range of vegetable crops, including cucurbit species. Considerable research has been conducted concerning production, quality, and establishment of vegetable transplants, particularly for certain solanaceous, cruciferous, and cucurbit crops (Dufault, 1986; Hall, 1992; Heins and Irwin, 1990 Latimer, 1991; McKee, 198 la, 198 lb). In Georgia, only a few growers currently use transplants to establish summer squash; however, this practice may increase as seed costs rise and more growers use plastic mulches in squash production. Therefore, information on using transplants to produce summer squash is needed. Several investigations have concentrated on the influence of transplant age on subsequent crop performance. Yields of tomato (Lycopersicon esculentum Mill.) transplants ranging from 3 to 6 weeks old either increased linearly with age (Weston and Zandstra, 1989) or were not influenced by transplant age (Leskovar et al., 1991). Bell pepper (Capsicum annuum L.) generally had increased fruit set and early yields when transplant age was increased from 30 to 77 days (McCraw and Greig, 1986; Weston, 1988). Therefore, the effect of transplant age on subsequent crop yields varies.

The issue of transplant age and its possible influence on crop performance is important since growers often contract to receive transplants at specific times and weather conditions may not be ideal for immediate planting in the field. There are concerns in these situations as to whether older transplants will perform sat-

Received for publication 19 Oct. 1992. Accepted for publication $13 \mathrm{~km}$. 1993. A contribution of the Univ. of Georgia Agricultural Experiment Station, Georgia Station, Griffin, supported by state and Hatch Act funds. The cost of publishing this paper was defrayed in part by the payment of page charges. Under postal regulations, this paper therefore must he hereby marked advertisement solely to indicate this fact. isfactorily once conditions are favorable for planting. The objective of this research was to examine the influence of transplant age on growth and yield of two commonly grown summer squash cultivars.

Experiments were conducted under greenhouse and field conditions during 1992. Transplants for both experiments were grown in flats containing seventy-two $4.0-\mathrm{cm}^{2} \times 5.7$ $\mathrm{cm}$-deep cells. Growing medium for the transplants was Metro-Mix 300 (W.R. Grace and Co., Cambridge, Mass.). Single seeds of 'Dixie' and 'Senator' squash were planted $2 \mathrm{~cm}$ deep in each cell. Seeds were planted at different times so that transplants of designated ages were available for planting on a common date. Transplants were watered daily and fertilized three times weekly with a solution of $20 \mathrm{~N}-$ $8.8 \mathrm{P}-16.6 \mathrm{~K}$ plus micronutrients at $200 \mathrm{ppm}$ N. Minima and maxima greenhouse temperatures during transplant production were 20 to

Transplants for the greenhouse experiment $21 \mathrm{C}$ and 25 to $30 \mathrm{C}$, respectively. were 10, 14,21,28, or 35 days old. On 11 Feb. 1992, transplants of all ages of each cultivar were planted into 7.6-liter containers of RediEarth growing medium (W.R. Grace and Co.). Nine plants of each age group were arranged in a randomized block design, with three replications, on a greenhouse bench at a plant density of 4.7 plants $/ \mathrm{m}^{2}$. The plants were watered as needed during the experiment, and a $17 \mathrm{~N}-$ $2.6 \mathrm{P}-10 \mathrm{~K}$ plus micronutrient controlled-release fertilizer was surface-applied at planting at 10 $\mathrm{g} /$ container. Plants were destructively sampled 10,22, and 29 days after transplanting (DAT) to determine shoot and root dry weight. Roots were washed free of soil by hand. Three plants from each treatment were sampled on each date. The plants designated for sampling 29 DAT were nondestructively monitored during the experiment to quantify leaf area production and flowering dynamics. Leaf area was estimated two to three times weekly using the procedure described by NeSmith (1992). Flower sex and count were determined two to three times weekly; petals were removed each time to aid counting.

Transplants for the field experiment were 10,20, and 30 days old. Also included in the field study was a directly seeded treatment for comparison. On 11 May 1992, seeds and transplants of all ages for each cultivar were handplanted in field plots at Griffin, Ga. The soil type was a Cecil sandy clay loam (clayey, kaolinitic, thermic Typic Hapludult). Rows were $0.9 \mathrm{~m}$ wide, plant spacing was $0.6 \mathrm{~m}$, and plant population density was 1.8 plants $/ \mathrm{m}^{2}$. A small amount of water was applied by hand to each transplant after planting. The experiment was a $2 \times 4$ factorial randomized completeblock design with three replications. Each plot was four rows wide by $6 \mathrm{~m}$ long, with 10 plants per row.

Fertilizer applications consisted of $10 \mathrm{~N}-$ $4.4 \mathrm{P}-8.3 \mathrm{~K}$ at $230 \mathrm{~kg} \cdot \mathrm{ha}^{-1}$ preplant incorporated, and $34 \mathrm{~N}-0 \mathrm{P}-0 \mathrm{~K}$ at $165 \mathrm{~kg} \cdot \mathrm{ha}$ sidedressed 2 weeks after planting. Overhead sprinkler irrigation was used to supplement rainfall.

Plant sampling for the field experiment

Table 1. Shoot and root dry weights of 10-, 14-,21-, 28-, and 35-day-old greenhouse-grown 'Dixie' and 'Senator' summer squash transplants 10,22, and 29 days after transplanting (DAT).

\begin{tabular}{|c|c|c|c|c|c|c|}
\hline \multirow{3}{*}{$\begin{array}{l}\text { Transplant } \\
\text { age } \\
\text { (days) }\end{array}$} & \multicolumn{6}{|c|}{ Dry wt } \\
\hline & \multicolumn{2}{|c|}{10 DAT } & \multicolumn{2}{|c|}{22 DAT } & \multicolumn{2}{|c|}{29 DAT } \\
\hline & Dixie & Senator & Dixie & Senator & Dixie & Senator \\
\hline \multicolumn{7}{|c|}{ Shoot wt (g/plant) } \\
\hline 10 & 0.7 & $1.2 *$ & 4.2 & $6.5^{*}$ & 19.6 & $31.3^{*}$ \\
\hline 14 & 1.2 & $1.7^{\mathrm{NS}}$ & 8.1 & $13.3^{*}$ & 23.2 & $34.9 *$ \\
\hline 21 & 2.0 & $2.2^{\mathrm{NS}}$ & 8.7 & $16.2^{*}$ & 23.9 & $40.8^{*}$ \\
\hline 28 & 2.2 & $2.6^{\mathrm{Ns}}$ & 7.6 & $11.1^{\mathrm{Ns}}$ & 20.0 & $39.2 *$ \\
\hline 35 & 2.4 & $2.8_{* *}^{\mathrm{NS}}$ & 5.5 & $7.4^{\mathrm{Ns}}$ & 16.4 & $34.5^{*}$ \\
\hline Linear & & & & & & \\
\hline Quadratic & NS & NS & ** & *** & * & ** \\
\hline \multicolumn{7}{|c|}{ Root wt (g/plant $)$} \\
\hline 10 & 0.1 & $0.2^{\mathrm{ss}}$ & 0.5 & $0.5^{\mathrm{Ns}}$ & 1.9 & $5.0 *$ \\
\hline 14 & 0.2 & $0.2^{\mathrm{vs}}$ & 1.2 & $1.7^{\mathrm{NS}}$ & 2.6 & $2.0^{*}$ \\
\hline 21 & 0.4 & $0.4^{\mathrm{NS}}$ & 2.2 & $4.1^{\mathrm{Ns}}$ & 2.5 & $10.9 *$ \\
\hline 28 & 0.4 & $0.6^{\text {vs }}$ & 1.3 & $3.3^{\mathrm{Ns}}$ & 1.9 & $9.7 *$ \\
\hline 35 & 0.4 & $0.3^{\mathrm{Ns}}$ & 0.9 & $1.4^{\mathrm{Ns}}$ & 1.7 & $7.9^{*}$ \\
\hline Linear & NS & NS & ** & ** & NS & ** \\
\hline Quadratic & NS & NS & ** & ** & NS & $* *$ \\
\hline
\end{tabular}

Nonsignificant or significant at $P \leq 0.05$ or 0.01 , respectively. 
was similar to that of the greenhouse experiment. Plant samples were taken 10,20, and 30 DAT to determine leaf area and plant dry weight. Two plants were sampled from a designated sampling row on each date in each replication for a total of six plants per treatment. The sampled plants were taken such that neighboring plants were located on all sides. Another row in each plot of each replication was designated as the harvest row. This row was bordered by an undisturbed row on each side. Flowers were counted on three plants in each of the harvest rows as described for the greenhouse experiment, Yields were determined on the entire harvest row by weighing and counting the fruit at several harvest intervals. Only those fruit $25 \mathrm{~cm}$ in diameter were harvested at each interval. Flowers were counted and harvested two to three times weekly. Fruit were harvested at least three times for each treatment; therefore, fruit were not harvested from all treatments the same number of times.

Analyses of variance were conducted to determine cultivar and transplant age main effects and interactions. Interactions were significant for most sampling dates under greenhouse and field conditions. Hence, regression analyses were performed on each cultivar separately to determine the effect of transplant age on plant dry weight and leaf area. For the field study, the seeded control was treated as a 0day-old transplant in the regression analyses.
Least significant difference tests were conducted to determine cultivar differences in each transplant age group. For data presented over time, standard errors were calculated.

The greenhouse experiment was designed to determine the range of transplant ages that should be examined under field conditions. In terms of shoot and root dry weight gain after transplanting by 29 DAT, 21 days seemed to be nearly optimum (Table 1). Shoot dry weight had increased linearly with transplant age at 10 DAT, and, by 22 DAT, transplant age effect was positively linear and negatively quadratic on root and shoot dry weights. 'Senator' had higher shoot and root weights than 'Dixie' by 29 DAT. A similar cultivar $\times$ transplant age trend was observed for whole-plant leaf area (data not presented). Compared to the 21 -dayold transplants, the first 10 to 15 leaves of the 35-day-old transplants were restricted in final leaf size by the extended period in small containers (Fig. 1), a result that is consistent with previous findings concerning squash response to root restriction (NeSmith, 1993a, 1993b). The difference in leaf area between the 21- and 10-day-old transplants primarily was because the older transplants had more leaves at sampling.

Female flower production was related to transplant age (Fig. 2). The older the transplant, the earlier open female flowers were present. Yields were not obtained from the greenhouse plants. Hence, it was not possible to determine if the older transplants would have produced marketable fruit before the other treatments.

Based on greenhouse results, 10-,20-, and 30-day-old transplants were selected for the field trial. Also, a directly seeded control was added to determine the potential benefit of using transplants of any age. The effect of transplant age was linear for shoot dry weight and leaf area for each cultivar at 10 and 20 DAT (Table 2). By 30 DAT, transplant age effect was positively linear and negatively quadratic. Ten-day-old 'Dixie' transplants had the highest dry weight and leaf area by 30 DAT, whereas 20-day-old 'Senator' transplants had the highest dry weight and leaf area on the same sampling date. Dry weight was higher and leaf area of all transplant ages was larger for both cultivars than for the directly seeded plants for the first 30 days of this experiment. The negative quadratic responses at 30 DAT suggest that the vegetative growth rate decreased for the 30-day-old transplants, most likely due to the earlier presence of reproductive sinks.

Field flowering results (data not presented) generally were consistent with those in the greenhouse, although the time difference between female flower appearance among transplant ages was not as great as observed in the greenhouse. All transplants produced flowers before those directly seeded. There was as much as a 20- and 26-day difference in time to
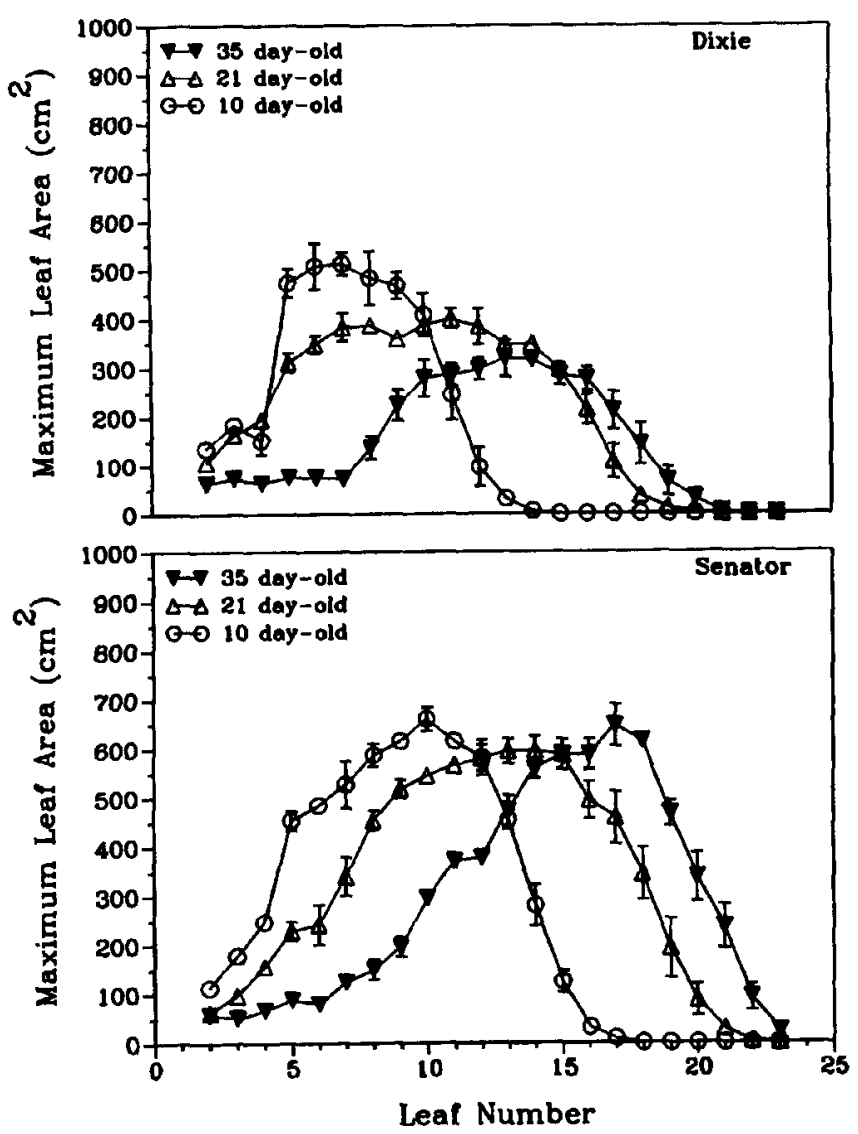

Fig. 1. Maximum individual leaf area of 10-,21-, and 35-day-old 'Dixie' and 'Senator' summer squash transplants grown under greenhouse conditions for 29 days after transplanting. Vertical bars represent SES, $\mathrm{n}=3$.

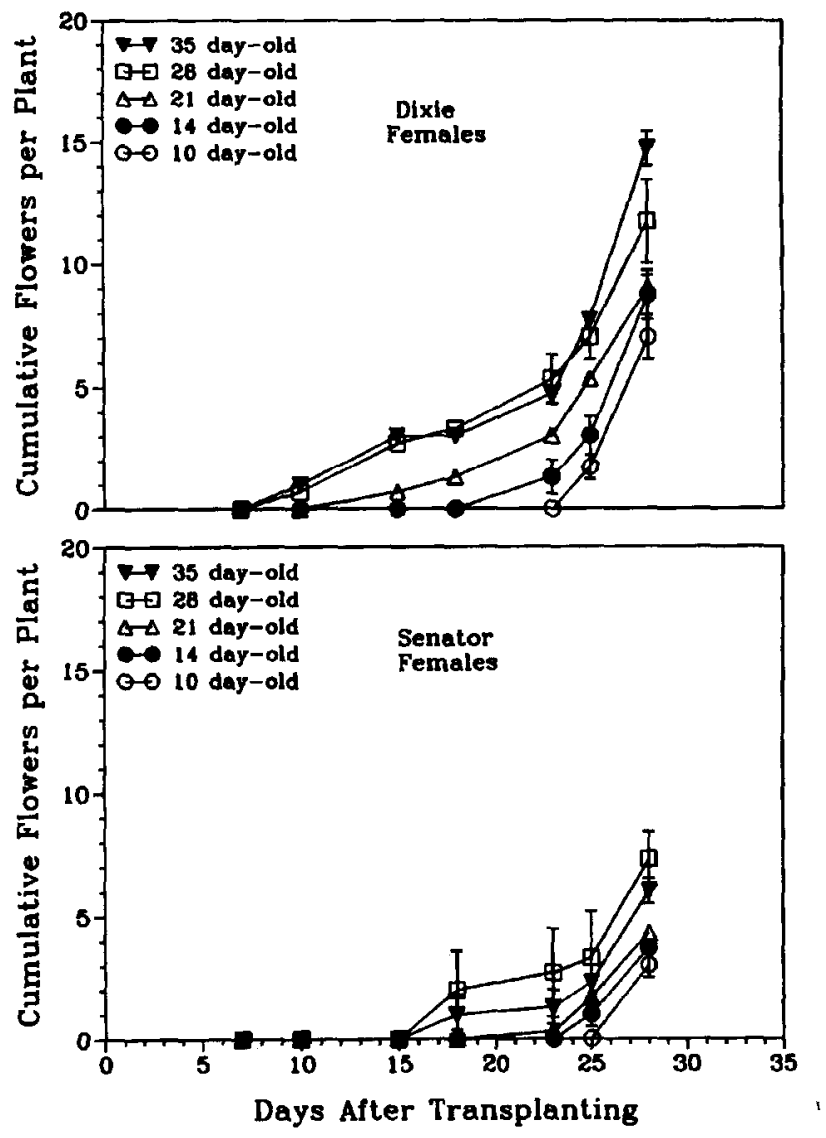

Fig. 2. Cumulative female flower count of 10-,14-,21 -,28-, and 35-dayold 'Dixie' and 'Senator' summer squash transplants grown under greenhouse conditions. Vertical bars represent SES, $\mathrm{n}=3$. 
Table 2. Shoot dry weight and leaf area of seeded and 10-, 20-, and 30-day-old field-grown 'Dixie' and 'Senator' summer squash transplants 10, 20, and 30 days after transplanting (DAT).

\begin{tabular}{|c|c|c|c|c|c|c|}
\hline \multirow{3}{*}{$\begin{array}{l}\text { Transplant } \\
\text { age } \\
\text { (days) } \\
\end{array}$} & \multicolumn{6}{|c|}{ Dry wt } \\
\hline & \multicolumn{2}{|c|}{10 DAT } & \multicolumn{2}{|c|}{20 DAT } & \multicolumn{2}{|c|}{$30 \mathrm{DAT}$} \\
\hline & Dixie & Senator & Dixie & Senator & Dixie & Senator \\
\hline \multicolumn{7}{|c|}{ Shoot wt (g/plant) } \\
\hline Seeded & 0.0 & $0.0^{\mathrm{ss}}$ & 0.9 & $1.1^{\mathrm{Ns}}$ & 10.6 & $15.7^{\mathrm{Ns}}$ \\
\hline 10 & 0.8 & $0.9^{\mathrm{Ns}}$ & 5.3 & $7.8^{\mathrm{Ns}}$ & 29.5 & $48.0^{*}$ \\
\hline 20 & 1.6 & $1.8^{\mathrm{Ns}}$ & 4.5 & $9.0^{*}$ & 18.8 & $65.9^{* *}$ \\
\hline 30 & 2.4 & $2.8^{\mathrm{Ns}}$ & 6.6 & $11.3^{*}$ & 16.0 & $54.6^{* *}$ \\
\hline Linear & * & ** & $* *$ & * & * & ** \\
\hline Quadratic & NS & NS & NS & NS & $* *$ & $* *$ \\
\hline \multicolumn{7}{|c|}{ Leaf area $\left(\mathrm{cm}^{2} /\right.$ plant $)$} \\
\hline Seeded & 0 & $0^{\text {Ns }}$ & 161 & $225^{\star s}$ & 1790 & $2508^{\mathrm{NS}}$ \\
\hline 10 & 112 & $162^{\text {Ns }}$ & 990 & $1239^{\mathrm{NS}}$ & 4969 & $6655^{\mathrm{NS}}$ \\
\hline 20 & 218 & $262^{\mathrm{Ns}}$ & 891 & $1350^{\text {ns }}$ & 3239 & $9694^{* *}$ \\
\hline 30 & 238 & $361^{\mathrm{Ns}}$ & 1155 & $1895^{\circ}$ & 2309 & $8379^{* *}$ \\
\hline Linear & *** & * & $* *$ & $*$ & $* *$ & ** \\
\hline Quadratic & NS & NS & NS & NS & ** & * \\
\hline
\end{tabular}

${ }_{\mathrm{Ns},+,+*}$ Nonsignificant or significant at $P \leq 0.05$ or 0.01 , respectively.
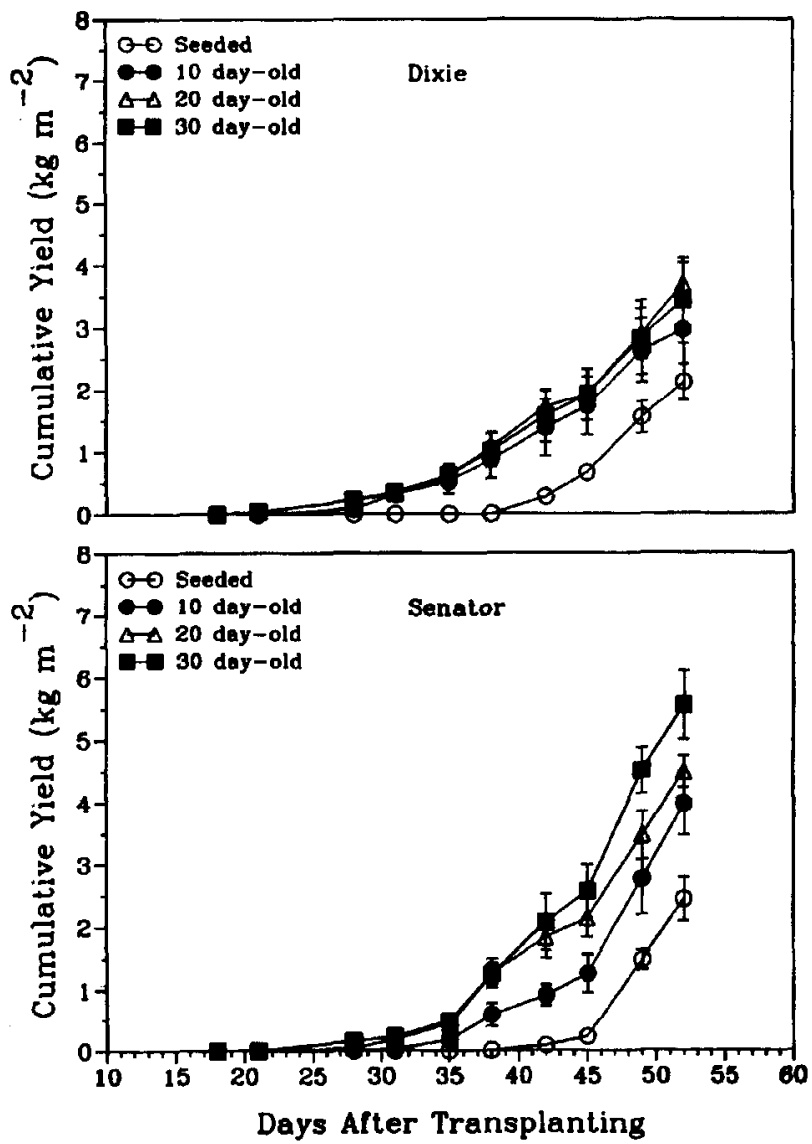

Fig. 3. Cumulative fruit yield of directly seeded and 10-, 20-, and 30-day-old transplants of 'Dixie' and 'Senator' summer squash grown under field conditions, Vertical bars represent SE, $\mathrm{n}=3$.

female flower appearance between transplants and directly seeded plots of 'Senator' and 'Dixie', respectively.

All 'Dixie' transplant ages produced similar yields at about the same time (Fig. 3). There were no observable differences in early or total yields among the various transplant ages for this cultivar over the harvest times of this experiment. The 20- and 30-day-old 'Senator' transplants yielded similarly for the first 45
DAT; thereafter, the 30-day-old transplants had higher cumulative yield. The 10-day-old transplants yielded less than the older ones over the same time period. Overall, transplants of both cultivars produced measurable yield 10 to 15 days earlier than plants in the directly seeded plots. Fruit counts reflected results similar to fruit yield, and there was no appreciable difference in fruit sizes (data not presented). All transplants for each cultivar produced more fruit than the directly seeded plants during the field experiment. However, total yield potential of the directly seeded control was not obtained, as plants in this treatment were harvested only three to four times.

The results of the greenhouse and field experiments indicate that transplant age influences growth and establishment of 'Dixie' and 'Senator' summer squash. The growth differences did not result in substantial early or total yield differences, however. Squash transplants ranging from 10 to 30 days old may yield equally well under field conditions. However, earlier yields can be achieved for these summer squash cultivars when using transplants instead of conventional seeding. Based on these experimental results, growers should strive to transplant 21-day-old squash. The 10-day-old transplants were difficult to remove from the cell packs due to the lack of substantial root development, and they were more subject to breakage. While the 30-day old transplants yielded satisfactorily, it is not clear how long they could be kept before yields would diminish. A 21-day-old target age for transplants would give $\approx 10$ days of flexibility in field planting and prevent additional transplant aging from reducing yields.

\section{Literature Cited}

Dufault, R.J. 1986. Influence of nutritional conditioning on muskmelon transplant quality and early yield. J. Amer. Soc. Hort. Sci. 111:698703

Hall, M.R. 1989. Cell size of seedling containers influences early vine growth and yield of transplanted watermelon. HortScience 24:771-773.

Heins, R. and J. Irwin. 1990. Understanding and applying DIF. Greenhouse Grower 8(2):73-76.

Latimer, J.G. 1991. Mechanical conditioning for control of growth and quality of vegetable transplants. HortScience 26:1456-1461.

Leskovar, D.I., D.J. Cantliffe, and P.J. Stoffella. 1991. Growth and yield of tomato plants in response to age of transplants. J. Amer. Soc. Hort. Sci. 116:416-420.

McCraw, B.D. and J.K. Greig. 1986. Effect of transplant age and pruning procedure on yield and fruit-set of bell pepper. HortScience 21:430431.

McKee, J.M.T. 198 la. Physiological aspects of transplanting vegetables and other crops. I. Factors which influence reestablishment. Hort. Abstr. 51:265-272.

McKee, J.M.T. 198 lb. Physiological aspects of transplanting vegetables and other crops. 11 . Methods used to improve transplant establishment. Hort. Abstr. 51:355-368.

NeSmith, D.S. 1992. Estimating summer squash leaf area nondestructively. HortScience 27:77.

NeSmith, D.S. 1993a. Influence of root restriction on two cultivars of summer squash (Cucrbita pepo L.). J. Plant Nutr. 16:421-431.

NeSmith, D.S. 1993b. Summer squash response to root restriction under different light regimes. J. Plant Nutr. 16:765-780

Weston,L.A. 1988. Effect of flat cell size, transplant age, and production site on growth and yield of pepper transplants. HortScience 23:709-711.

Weston, L.A. and B.H. Zandstra. 1989. Transplant age and $\mathrm{N}$ and $\mathrm{P}$ nutrition effects on growth and yield of tomatoes. HortScience 24:88-90. 